\title{
State of the antioxidant protection system of rat liver in ischemia and reperfusion
}

\author{
K.A. Popov, I.M. Bykov, I.Y. Tsymbalyuk, Ya.E. Denisova, A.N. Stolyarova, \\ E.A. Azimov, L.A. Shurygina
}

Kuban state medical university, Krasnodar, Russian Federation

\begin{abstract}
Purpose: determination of the state of the antioxidant protection system of the cytosolic fraction and suspension of rat liver mitochondria after experimental ischemia and reperfusion. Materials and methods: the study was conducted using white mature rats, divided into 3 groups: the control group $(n=15)$; The 2nd group of animals $(n=15)$, from which the liver was taken after 15 minutes of liver ischemia; the 3rd group of rats $(n=15)$, from which the liver was taken after a 15 -minute reperfusion period, followed by a 15-minute ischemic period. Mitochondrial suspension and cytosolic fraction were isolated from liver tissue. Results: the obtained research results showed the presence of certain pathobiochemical changes in the suspension of mitochondria and the cytosolic fraction after ischemia or reperfusion. In the mitochondrial suspension during the reperfusion period it was found an adaptive increase in the activity of glutathione peroxidase by $39 \%$ and glutathione reductase by $61 \%$. In the cytosolic fraction, it was the most remarkable increase of the total antioxidant capacity by $38 \%$ already during ischemia and a progressive decrease in the level of reduced glutathione form by $26 \%$ in ischemic and $55 \%$ in reperfusion period. The change in the state of the antioxidant system occurred against the background of an increase in the number of products of oxidative modifications of biomolecules by $40 \%$ during ischemia and 2.2 times after reperfusion. Conclusion: The results indicate the need to develop not only a mitochondria-oriented correction of oxidative disorders, but also active support for the components of the cytosol, which provide the main accumulation of free radical damage products and their subsequent removal from the cell, which is essential for survival.
\end{abstract}

Key words: liver, ischemia, reperfusion, antioxidative system, mitochondria

Author Contributions. Popov K.A. - design and performance of experimental procedure, article writing; Bykov I.M.concept and design of study, results and discussion; Tsymbalyuk I.Y. - planning and performance of experimental procedure with test animals; Denisova Y.E._- performance of experimental procedure, statistical processing of results; Stolyarova A.N.performance of experimental procedure, analysis, results and discussion; Azimov E.A.—- performance of experimental procedure, Shurygina L.A. - performance of experimental procedure, analysis, results and discussion.

Conflict of Interest Statement. The authors declare no conflict of interest.

Funding: This work was supported by the State Task of the Ministry of Health Care of the Russian Federation by state assignment (28.01.2015, part 1, chapter 1).

Received 17.01.2020. Accepted 30.01.2020

For citation Popov K.A., Bykov I.M., Tsymbalyuk I.Y., Denisova Ya.E., Stolyarova A.N., Azimov E.A., Shurygina L.A. State of the antioxidant protection system of rat liver in ischemia and reperfusion. RUDN Journal of Medicine. 2020 Mar; 24 (1): 93-104. DOI: 10.22363/2313-0245-2020-24-1-93-104

(C) Popov K.A., Bykov I.M., Tsymbalyuk I.Y., Denisova Ya.E., Stolyarova A.N., Azimov E.A., Shurygina L.A. 2020 This work is licensed under a Creative Commons Attribution 4.0 International License https://creativecommons.org/licenses/by/4.0/ 


\title{
Состояние системы антиоксидантной защиты печени крыс при ишемии и реперфузии
}

\author{
К.А. Попов, И.М. Быков, И.Ю. Цымбалюк, Я.Е. Денисова, А.Н. Столярова, \\ Э.А. Азимов, Л.А. Шурыгина
}

Кубанский государственный медицинский университет, Краснодар, Российская Федерация

\begin{abstract}
Аннотация. Цель: определение состояния системы антиоксидантной защиты цитозольной фракции и суспензии митохондрий печени крыс после экспериментальной ишемии и реперфузии. Материалы и методы: исследование проведено с использованием белых половозрелых крыс, разделенных на 3 группы: контрольная группа (n=15); 2-я группа животных (n=15), у которых забирали печень после 15-ти минут ишемии печени; 3-я группа крыс (n=15), у которых забирали печень после 15-минутного реперфузионного периода, следовавшего за 15-минутным ишемическим. Из ткани печени выделяли митохондриальную суспензию и цитозольную фракцию. Результаты: Полученные результаты исследований показали наличие особенностей патобиохимических изменений в суспензии митохондрий и цитозольной фракции после ишемии или реперфузии. В митохондриальной суспензии в период реперфузии установлено адаптационное увеличение активности глутатионпероксидазы на $39 \%$ и глутатионредуктазы на $61 \%$. В цитозольной фракции наиболее значительно было увеличение общей антиоксидантной активности на 38\% уже в период ишемии и прогрессирующее снижение уровня восстановленной формы глутатиона на $26 \%$ в ишемический и на $55 \%$ в реперфузионный период. Изменение состояния антиоксидантной системы происходило на фоне роста количества продуктов окислительных модификаций биомолекул на $40 \%$ в период ишемии и в 2,2 раза после реперфузии. Заключение: результаты указывают на необходимость разработки не только митохондриально-ориентированной коррекции окислительных нарушений, но и на активную поддержку компонентам цитозоля, обеспечивающим основное накопление продуктов свободнорадикальных повреждений и последующее удаление их из клетки, что является исключительно необходимым для выживания.
\end{abstract}

Ключевые слова: печень, ишемия, реперфузия, антиоксидантная система, митохондрия

Участие авторов: Попов К.А.— дизайн и выполнение лабораторной части исследования, написание текста статьи; Быков И.М. — концепция и дизайн исследования, обсуждение результатов; Цымбалюк И.Ю.— непосредственное планирование и выполнение экспериментальной работы с лабораторными животными; Денисова Я.Е.— выполнение лабораторной части исследования, статистическая обработка результатов; Столярова А.Н.— выполнение лабораторной части исследования, анализ и обсуждение результатов; Азимов Э.А.— выполнение лабораторной и экспериментальной части исследования, Шурыгина Л.А.— - выполнение лабораторной части исследования, анализ и обсуждение результатов. Информация о финансировании. Работа выполнена при поддержке государственного задания Министерства здравоохранения Российской Федерации (от 28.01.2015 г.ч. 1, раздел 1) «Осуществление прикладных научных исследований, в том числе проведение доклинических исследований лекарственных средств и клинических исследований лекарственных препаратов».

Информация о конфликте интересов. Авторы заявили об отсутствии конфликта интересов. Поступила 17.01.2020. Принята 30.01.2020.

Для цитирования: Попов К.А., Быков И.М., Цымбалюк И.Ю., Денисова Я.Е., Столярова А.Н., Азимов Э.А., Шурыгина Л.А. Состояние системы антиоксидантной защиты печени крыс при ишемии и реперфузии // Вестник Российского университета дружбы народов. Серия: Медицина. 2020. T. 24. № 1. С. 93-104. DOI: 10.22363/2313-0245-2020-24-1-93-104 
Disorders of oxidative homeostasis, including hypoenergetic states and oxidative stress, are the leading pathobiochemical mechanisms of the development and progression of ischemic and reperfusion injuries of various organs. During the ischemic period, a sharp decrease in the oxygen tension in the tissue naturally leads to a transition to less effective anaerobic energy processes. At the same time, the oxygen residues against the background of dysregulation of the respiratory chain form their active forms to a greater extent, which already in the period of turning off the blood flow stimulate the development of free-radical damage. The resumption of blood supply and the transition to the reperfusion period are accompanied by an even more powerful intensification of oxidative stress against the background of relative hyperoxia. Currently, it is known that the damage of the reperfusion period makes the leading contribution to the total damage of the organ and the development of its subsequent dysfunction [1-2].

Understanding the sequence of events occurring in the dynamics of ischemic-reperfusion syndrome injuries at different levels can contribute to the development of new pathogenetically justified methods of correction of such pathological processes [3-5]. The relevance of correction of such disorders is due to the fact that hypoxia and reoxygenation are universal pathological processes and are the basis of many disorders of cardiovascular activity, found in surgical practice, including organ transplantation.

The so-called Pringle technique is often found in surgical Hepatology. It is a compression of the hepaticduodenal ligament in order to prevent blood loss during surgical interventions on the liver parenchyma. The use of this technique is limited by the risks of postoperative liver failure due to ischemic reperfusion injuries. The similar complex of pathobiochemical processes develops during the liver transplantation, which is often the only way to treat hepatitis and cirrhosis [6-8].

The purpose of this study was to determine the state of the antioxidant protection system of the cytosol fraction and suspension of the rat liver mitochondria after experimental ischemia and reperfusion.

\section{Material and methods}

White non-linear male rats weighing 220-250 grams ( $n=50)$ were used for the study. All laboratory animals were kept in the conditions of the vivarium of FSBEI HE KubGMU of the Ministry of Health of Russia in appropriate conditions.

All experimental work with the participation of animals was performed in a specialized operating vivarium, while all painful manipulations were carried out after preliminary general anesthesia using Zoletil 100 (Virbac, France) 10 mg / kg intramuscularly. The study was carried out in accordance with the requirements of the "European Convention for the Protection of Vertebrate Animals” (Strasbourg, 1986) and after approval by an independent ethical committee (protocol No. 51 of 05.23.2017).

Experimental animals were divided into 3 groups: control group is the group of rats that underwent a medians laparotomy without further modeling of the pathological process (pseudo-operated animals, group $1, n=20)$; group 2 is group of rats $(n=15)$ that underwent vascular liver exclusion by clamping an analog of the hepatoduodenal ligament for 15 minutes after which the liver was taken without restoring blood flow; group 3 is a group of rats $(n=15)$ whose liver was taken after a 15-minute reperfusion period following a 15-minute ischemic period. The liver was immediately placed in a cold medium consisting of at least one-third of the frozen medium to isolate the mitochondrial suspension [9]. In the laboratory of the Department of fundamental and clinical biochemistry the liver immediately after the experiment was crushed and homogenized in the same sucrose medium ( $0.25 \mathrm{M}$ sucrose containing EGTA and $\mathrm{Mg}$ ions in $0.02 \mathrm{M}$ tris- $\mathrm{HCl}$ buffer with $\mathrm{pH}=7.4$ ). After homogenization they were centrifuged at $1000 \mathrm{~g}$ for 5 minutes to remove large fragments whole undisturbed cells, red blood cells, ect. Further after centrifugation for 10 minutes at 12,000 $\mathrm{g}$ the supernatant was used as a cytosolic (postmitochondrial) fraction and the pellet was washed again under the same conditions and prepared from it a working mitochondrial suspension. Protein concentration was determined in the cytosolic fraction and mitochondrial suspension using the Bradford method [10]. The calculation of the content of metabolites or enzyme activity in the subsequent was 
based on the protein content in the sample.

The state of the antioxidant defense system was evaluated by determining the total antioxidant capacity of ferrum-reducing method FRAP [11], catalase activity, glutathione peroxidase activity, glutathione reductase, reducible glutathione count [12-13]. The level of intensity of oxidative processes revealed the accumulation of diene conjugates in the studied biofluids.

Statistical data handling was performed using Stat plus LE and Excel for Windows. The nature of the data division was evaluated using the Shapiro-Wilk statistic, the data were presented as a median and the 1st and 3rd quartiles (Q1 and Q3). The nonparametric Mann-Whitney U-test was determined to assess the significance of differences between the indicators of the studied groups of animals. The differences were considered statistically significant at $\mathrm{p}<0.05$.

\section{Results and discussion}

Determination of indicators of antioxidant defense system and mitochondrial fractions of rat liver cytosol after ischemia or ischemia / reperfusion showed the presence of characteristic differences at different times and in different subcellular compartments. In the mitochondrial suspension (table. 1) after 15 minutes of ischemia and without restoring of blood flow a slight increase in total antioxidant capacity was noted by $15 \%$ relative to the target. In the same period an increase $7 \%$ activity of glutathione reductase was observed. These changes are associated more likely with rapid adaptive changes aimed at maintaining adequate oxidative homeostasis. At the same time the catalase activity was reduced by $27 \%$. This is due to the relatively low rate of formation of hydrogen peroxide during this period. The activity of glutathione peroxidase did not undergo significant changes although this enzyme is primarily responsible for the utilization of peroxides in mitochondria. The strengthening of free radical processes already in the ischemic period is confirmed by an increase in the accumulation in the mitochondrial suspension of intermediate products of lipid peroxidation, i.e. diene conjugates the content of which in the mitochondria of the liver of rats of 2nd group increased by $12.5 \%$. Given the short duration of the pathological process of only 15 minutes of vascular excretion the recorded changes should not seem insignificant.

Indices of the system of antioxidant protection of suspension received from mitochondria

Table 1 of rat liver after ischemic and reperfusion damage ( $\mathrm{Me}(\mathrm{p0}, 25 / \mathrm{p0}, 75))$

\begin{tabular}{|c|c|c|c|}
\hline \multirow{2}{*}{ Studied indices } & \multicolumn{3}{|c|}{ Test groups } \\
\hline & 1 (control) & 2 (ischemia) & 3 (reperfusion) \\
\hline $\begin{array}{l}\text { Total antioxidant capacity, mM Vit C/ mg of } \\
\text { protein }\end{array}$ & $\begin{array}{c}2,0 \\
(1,9 / 2,1)\end{array}$ & $\begin{array}{c}2,3^{\star} \\
(2,1 / 2,5) \\
\end{array}$ & $\begin{array}{c}2,6^{*} \\
(2,3 / 2,7) \\
\end{array}$ \\
\hline CAT, $\mathrm{nmol} /(\min \times \mathrm{mg}$ of protein $)$ & $\begin{array}{c}992,3 \\
(945,1 / 1024,5) \\
\end{array}$ & $\begin{array}{c}726,1^{*} \\
(678,4 / 766,5) \\
\end{array}$ & $\begin{array}{c}919,6^{* \wedge} \\
(880,7 / 930,2) \\
\end{array}$ \\
\hline Glutathione peroxidase, $\mathrm{nmol} /(\min \times \mathrm{mg}$ of protein $)$ & $\begin{array}{c}86,8 \\
(82,4 / 89,5) \\
\end{array}$ & $\begin{array}{c}91,6 \\
(86,3 / 94,5) \\
\end{array}$ & $\begin{array}{c}120,6^{\star \wedge} \\
(112,8 / 126,2)\end{array}$ \\
\hline $\mathrm{GSH}, \mathrm{nmol} / \mathrm{mg}$ of protein & $\begin{array}{c}10,1 \\
(9,6 / 10,3) \\
\end{array}$ & $\begin{array}{c}9,6 \\
(9,5 / 10,2) \\
\end{array}$ & $\begin{array}{c}9,5 \\
(9,4 / 10,1) \\
\end{array}$ \\
\hline Diene conjugates, conv. units & $\begin{array}{c}0,08 \\
(0,07 / 0,09)\end{array}$ & $\begin{array}{c}0,10^{\star} \\
(0,09 / 0,10)\end{array}$ & $\begin{array}{c}0,08 \\
(0,07 / 0,09)\end{array}$ \\
\hline
\end{tabular}

Note:* - statistically significant differences $(p<0,05)$ from the same index of the 1 st group; ${ }^{\wedge}-$ statistically significant differences $(p<0,05)$ from index of the 2 nd group.

The more significant changes in state of the system of antioxidant protection of mitochondria were determined after 15 minutes of reperfusion in livers of rats from the 3rd (Table 1). In this group, the total antioxidant capacity kept increasing up to 30\% in comparison with the control values. The increase in 
activity of all studied enzymes was also revealed. The activity of glutathione peroxidase increased by 39\%, while the activity of glutathione reductase increased by $61 \%$ in comparison with indices of the control group. The catalase activity also increased by $27 \%$ in comparison with the values of the 2nd group, but the value of this index remained a bit lower than the control values. The concentration of reduced glutathione in mitochondrial suspension of liver in rats of the 3rd group remained at the level of the control group which certainly proved high capacity of antioxidant system of mitochondria. The level of diene conjugates determined within the mitochondrial suspension of liver in the 3rd group did not differ from the level of control group which proved the rapid recovery of mitochondrial structure and function after relatively long period of ischemic and reperfusion damage.

Indices of the system of antioxidant protection of cytoplasmic fractions received from rat liver after ischemic

Table 2 and reperfusion damage ( $\mathrm{Me}(\mathrm{p} 0,25 / \mathrm{p} 0,75))$

\begin{tabular}{|c|c|c|c|}
\hline \multirow{2}{*}{ Studied indices } & \multicolumn{3}{|c|}{ Test groups } \\
\hline & 1 (control) & 2 (ischemia) & 3 (reperfusion) \\
\hline Total antioxidant capacity, $\mathrm{mM}$ Vit $\mathrm{C} / \mathrm{mg}$ of protein & $\begin{array}{c}2,4 \\
(2,3 / 2,6)\end{array}$ & $\begin{array}{c}3,3^{\star} \\
(3,0 / 3,5)\end{array}$ & $\begin{array}{c}3,2^{*} \\
(3,0 / 3,4)\end{array}$ \\
\hline CAT, $\mathrm{nmol} /(\min \times \mathrm{mg}$ of protein $)$ & $\begin{array}{c}217,8 \\
(205,9 / 221,6)\end{array}$ & $\begin{array}{c}213,0 \\
(204,0 / 220,0)\end{array}$ & $\begin{array}{c}309,8^{\star \wedge} \\
(290,5 / 318,6)\end{array}$ \\
\hline Glutathione peroxidase, $\mathrm{nmol} /(\min \times \mathrm{mg}$ of protein $)$ & $\begin{array}{c}120,6 \\
(113,6 / 127,0)\end{array}$ & $\begin{array}{c}168,8^{\star} \\
(155,2 / 178,4)\end{array}$ & $\begin{array}{c}106,1^{\wedge} \\
(104,1 / 119,6)\end{array}$ \\
\hline $\mathrm{GSH}, \mathrm{nmol} / \mathrm{mg}$ of protein & $\begin{array}{c}8,0 \\
(7,8 / 8,2)\end{array}$ & $\begin{array}{c}5,8^{\star} \\
(5,6 / 6,2)\end{array}$ & $\begin{array}{c}3,6^{\star \wedge} \\
(3,4 / 4,0)\end{array}$ \\
\hline Diene conjugates, conv. units & $\begin{array}{c}0,10 \\
(0,09 / 0,11)\end{array}$ & $\begin{array}{c}0,14^{\star} \\
(0,13 / 0,15)\end{array}$ & $\begin{array}{c}0,22^{\star \wedge} \\
(0,19 / 0,23)\end{array}$ \\
\hline
\end{tabular}

Note:* - statistically significant differences $(p<0,05)$ from the same index of the 1 st group; ${ }^{\wedge}-$ statistically significant differences $(p<0,05)$ from index of the 2nd group.

In cytoplasmic (post-mitochondrial) fraction, the changes in enzymic activity were considered to be less reactive, but the more significant changes of non-enzymic components and the accumulation of diene conjugates were also detected (Table 2). So, at the ischemic period, the activity values of glutathione peroxidise increased by $40 \%$, but returned to their initial level at the reperfusion period. The activity of glutathione reductase changed in a similar way. In test animals of the 2nd group, the activity of this enzyme in the cytoplasmic fraction of liver increased by $8 \%$, while in animals of the 3rd group it did not differ from the control values. The catalase activity significantly increased after 15-minute reperfusion, in particular by $42 \%$ in comparison with the control values. The revealed changes may result from the primary catalase localization within the cytosol and peroxisomes as well as from the more important role of this enzyme in protection of cytosol and its structures in comparison with mitochondria. The total antioxidant capacity changed within the cytosol fraction in the same way that in mitochondria, but more significantly. In test animals of the 2nd - 3rd groups, the studied index increased by $37-38 \%$ in comparison with the values of the control group. The significant decrease in level of reduced glutathione in cytoplasmic fraction of rat liver was also revealed - by $26 \%$ after the ischemic period and by $55 \%$ after the reperfusion period respectively. The content of diene conjugates gradually increased in liver of test animals in all the studied groups. In cytoplasmic fraction of rat liver of the 2nd group, the level of diene conjugates increased by $40 \%$ while in rats of the 3rd group - by 2,2 times. We believe that the received results are conditioned by the adaptative character of changes in system of antioxidant protection with the increase in enzymic activity and in total antioxidant 
capacity. Furthermore, the main adaptative processes within the cytolysis take place at the ischemic period, while in the mitochondrial suspension they take place during reperfusion. In such conditions the cytosol plays the role of the buffer receiving the greater part of products of oxidative modifications of biomolecules and providing the main amount of reduced equivalents of glutathione for the further functioning of antioxidant system. Another highly reliable thesis is that during the process of excretion of mitochondrial suspension the damaged and destroyed organelles remain in the cytoplasmic fraction as well as their components; thus, the artificial image of "wellness" of metabolic systems of mitochondria is represented against the background of extensive pathobiochemical disorders within the cytoplasmic fraction. In our opinion, the chosen experimental model of pathobiochemical process is relatively mild and against its background the mitochondrial damage should not be expected; that's why the first thesis is considered to be more reliable. The whole image of pathological process is probably more complex and is composed of the buffer influence of cytosol and depletion of damaged mitochondrial components into it. One way or another, it is clear that for the objective assessment of the state of antioxidant system during the development of ischemic and reperfusion damages the indices of both mitochondrial suspension and cytoplasmic fraction should be evaluated. Furthermore, by the analysis of mitochondrial suspension the attention should be paid to the changes in enzymic activity of metabolic glutathione, while in the cytoplasmic fraction the attention should be paid to the changes in catalase activity, content of reduced glutathione, and products of oxidative modifications of biomolecules.

\section{Conclusion}

The results of the study proved the peculiarities of pathobiochemical changes in suspension of mitochondria and cytoplasmic fraction after 15 minutes of ischemia and the same period of reperfusion. In mitochondrial suspension, the adaptative increase in activity of glutathione peroxidase and glutathione reductase was detected, especially at the reperfusion period. In cytoplasmic fraction, the increase of total antioxidant capacity was the most significant at the ischemia period with the progressing decrease in the level of reduced glutathione against the background of growing number of products of oxidative modifications of biomolecules. The received results prove that it's necessary not only to develop the mitochondrial-oriented correction of oxidative disorders, but also to actively support the cytoplasmic components which provide the storage of products of free-radical damages and their further removal from the cells which is extremely important for surviving.

Нарушения окислительного гомеостаза, включающие гипоэнергетические состояния и окислительный стресс, являются ведущими патобиохимическими механизмами развития и прогрессирования ишемических и реперфузионных повреждений различных органов. В ишемический период резкое снижение напряжения кислорода в ткани закономерно ведет к переходу на менее эффективные анаэробные энергетические процессы. При этом остатки кислорода на фоне дисрегуляции дыхательной цепи образуют в большей степени свои активные формы, что уже в период выключения кровотока способствует развитию свободнорадикальных повреждений. Восстановление кровоснабжения и переход к реперфузионному периоду сопровождаются еще более мощной интенсификацией окислительного стресса на фоне относительной гипероксии. В настоящее время известно, что именно повреждения реперфузионного периода вносят ведущий вклад в общее повреждение органа и развитие последующей его дисфункции [1-2]. Понимание последовательности событий, происходящих в динамике развития повреждений ишемически-реперфузионного синдрома на разном уровне, может способствовать разработке новых патогенетически обоснованных способов коррекции таких патологических процессов [3-5]. Актуальность коррекции таких нарушений обусловлена тем, что гипоксия и реоксигенация являются универсальными патологическими процессами и лежат в основе многих нарушений сердечно-сосудистой деятельности, встречаются в хирургической практике, в том числе при трансплантации органов. 
В хирургической гепатологии часто встречается так называемый прием Прингла, представляющий пережатие печеночно-двенадцатиперстной связки с целью предотвращения кровопотерь при оперативных вмешательствах на паренхиме печени. Использование данного приема ограничивается рисками развития послеоперационной печеночной недостаточности вследствие ишемически-реперфузионных повреждений. Похожий комплекс патобиохимических процессов развивается и при трансплантации печени, часто являющейся единственным способом лечения гепатитов и цирроза [6-8].

Целью настоящего исследования было определение состояния системы антиоксидантной защиты цитозольной фракции и суспензии митохондрий печени крыс после экспериментальной ишемии и реперфузии.

\section{Материалы и методы}

Для проведения исследования использовали белых нелинейных самцов крыс массой 220250 грамм (n=50). Все лабораторные животные содержались в условиях вивария ФГБОУ ВО КубГМУ Минздрава России в надлежащих условиях. Все экспериментальные работы, выполняемые непосредственно с участием животных, выполнялись в специализированной операционной вивария, при этом все болезненные манипуляции осуществлялись после предварительной общей анестезии с использованием Золетила 100 («Virbac», France) 10 мг/кг внутримышечно. Проведение исследования осуществлялось в соответствии с требованиями «Европейской конвенции по защите позвоночных животных» (Страсбург, 1986) и после одобрения независимым этическим комитетом (протокол № 51 от 23.05.2017 г.).

Экспериментальные животные были разделены на 3 группы: контрольная группа - группа крыс, подвергавшихся срединной лапаротомии без дальнейшего моделирования патологического процесса (псевдооперированные животные, группа 1, n=20); 2-я группа - группа крыс (n=15), которым выполняли васкулярную эксклюзию печени путем пережатия аналога печеночно-двенадцатиперстной связки на 15 минут, после чего без восстановления кровотока забирали печень; 3-я группа - группа крыс (n=15), у которых забирали печень после 15минутного реперфузионного периода, следовавшего за 15-минутным ишемическим периодом. Печень сразу помещали в холодную среду, состоящую не менее чем из трети замерзшей среды, для выделения митохондриальной суспензии [9]. В лаборатории кафедры фундаментальной и клинической биохимии печень сразу после эксперимента измельчали и гомогенизировали в той же сахарозной среде $(0,25 \mathrm{M}$ сахарозы, содержащей ЭГТА и ионы Mg в 0,02 M трис-HCl буфере с $\mathrm{pH}=7,4)$. После гомогенизации центрифугировали при 1000 g в течение 5 минут для удаления крупных обломков, целых неразрушенных клеток, эритроцитов и прочего. Далее после центрифугирования в течение 10 минут при $12000 \mathrm{~g}$ супернатант использовали в качестве цитозольной (постмитохондриальной) фракции, а осадок еще раз отмывали в тех же условиях и готовили из него рабочую суспензию митохондрий. В цитозольной фракции и суспензии митохондрий определяли концентрацию белка с помощью метода Брэдфорд [10]. Расчет содержания метаболитов или активности ферментов в последующем вели исходя из содержания белка в образце.

Состояние системы антиоксидантной защиты оценивали путем определения общей антиоксидантной активности железо-восстанавливающим способом FRAP [11], каталазной активности, активности глутатионпероксидазы, глутатионредуктазы, содержания восстановленного глутатиона [12-13]. Об уровне интенсивности окислительных процессов судили по накоплению диеновых конъюгатов в исследуемых биожидкостях.

Статистическую обработку данных проводили с использованием пакета Stat plus LE и Excel для Windows. Характер распределения данных оценивали с помощью критерия Шапиро-Вилка, данные представляли в виде медианы и 1-го и 3-го квартилей (Q1 и Q3). Для оценки значимости различий между показателями исследуемых групп животных определяли непараметрический U-критерий Манна-Уитни. Различия считали статистически значимыми при уровне $\mathrm{p}<0,05$. 


\section{Результаты и обсуждение}

Определение показателей состояния системы антиоксидантной защиты митохондриальной и цитозольной фракций печени крыс после ишемии или ишемии/реперфузии показало развитие характерных отличий в разные периоды и в разных субклеточных компартментах. В митохондриальной суспензии (табл. 1) после 15-минутной ишемии и без восстановления кровотока отмечалось небольшое увеличение общей антиоксидантной активности — на 15\% относительно контрольных цифр. Также была зафиксирована в этот же период увеличенная на 7\% активность глутатионредуктазы. Данные изменения связаны скорее с быстрыми адаптационными перестройками, направленными на поддержание адекватного окислительного гомеостаза. При этом каталазная активность была снижена на 27\%, что мо- жет быть обусловлено в данный период небольшой скоростью образования именно пероксида водорода. Активность глутатионпероксидазы существенных изменений не претерпевала, хотя за утилизацию пероксидов в митохондриях ответственен в первую очередь это фермент. Усиление свободнорадикальных процессов уже в ишемический период подтверждается увеличением накопления в митохондриальной суспензии промежутоных продуктов перекисного окисления липидов - диеновых конъюгатов, содержание которых в митохондриях печени крыс 2-й группы было увеличенным на 12,5\%. Учитывая небольшую продолжительность патологического процесса — всего 15 минут васкулярной эксклюзии, зафиксированные изменения не должны казаться незначительными.

Показатели состояния системы антиоксидантной защиты суспензии митохондрий печени крыс после ишемического и реперфузионного поражения (Me(p0,25/p0,75))

\begin{tabular}{|c|c|c|c|}
\hline \multirow{2}{*}{ Исследуемые показатели } & \multicolumn{3}{|c|}{ Исследуемые группы } \\
\hline & 1 (контроль) & 2 (ишемия) & 3 (реперфузия) \\
\hline Общая АОА, мМ вит С/ мг белка & $\begin{array}{c}2,0 \\
(1,9 / 2,1)\end{array}$ & $\begin{array}{c}2,3^{\star} \\
(2,1 / 2,5) \\
\end{array}$ & $\begin{array}{c}2,6^{\star} \\
(2,3 / 2,7) \\
\end{array}$ \\
\hline ГПО, нмоль/(мин×мг белка) & $\begin{array}{c}86,8 \\
(82,4 / 89,5)\end{array}$ & $\begin{array}{c}91,6 \\
(86,3 / 94,5)\end{array}$ & $\begin{array}{c}120,6^{\star \Lambda} \\
(112,8 / 126,2)\end{array}$ \\
\hline GSH, нмоль/мг белка & $\begin{array}{c}10,1 \\
(9,6 / 10,3)\end{array}$ & $\begin{array}{c}9,6 \\
(9,5 / 10,2)\end{array}$ & $\begin{array}{c}9,5 \\
(9,4 / 10,1)\end{array}$ \\
\hline ДК, усл. ед. & $\begin{array}{c}0,08 \\
(0,07 / 0,09)\end{array}$ & $\begin{array}{c}0,10^{\star} \\
(0,09 / 0,10)\end{array}$ & $\begin{array}{c}0,08 \\
(0,07 / 0,09)\end{array}$ \\
\hline
\end{tabular}

Примечание: * - статистически значимые отличия $(p<0,05)$ от соответствующего показателя 1-й группы; ${ }^{\wedge}$ статистически значимые отличия $(p<0,05)$ от показателя 2-й группы.

Более выраженные изменения состояния системы антиоксидантной защиты митохондрий определены после 15-минутного реперфузионного периода в печени крыс 3-й группы (табл. 1). В данной группе продолжала увеличиваться общая антиоксидантная активность - возрастание данного показателя относительно контрольных цифр достигало 30\%. Наблюдалось увеличение активности всех трех изученных ферментов. Активность глутатионпероксидазы была увеличена на 39\%, активность глутати- онредуктазы - на 61\% относительно соответствующих показателей контрольной группы. Увеличена была также каталазная активность, относительно показателя 2-й группы, на 27\%, однако значение данного показателя оставалось несколько ниже контрольных цифр. Концентрация восстановленной формы глутатиона в митохондриальной суспензии печени крыс 3-й группы поддерживалась на уровне контрольной группы, что, безусловно, отражает высокую мощность антиоксидантной системы ми- 
тохондрий. Уровень диеновых конъюгатов, определяемых в митохондриальной суспензии печени 3-й группы, не отличался от уровня контрольной группы, что может свидетельствовать о быстром восстановлении структуры и функции митохондрий после относительно непродолжительных ишемических и реперфузионных повреждений.

Показатели состояния системы антиоксидантной защиты цитозольной фракции печени крыс

Таблица 2 после ишемического и реперфузионного поражения (Me(p0,25/p0,75))

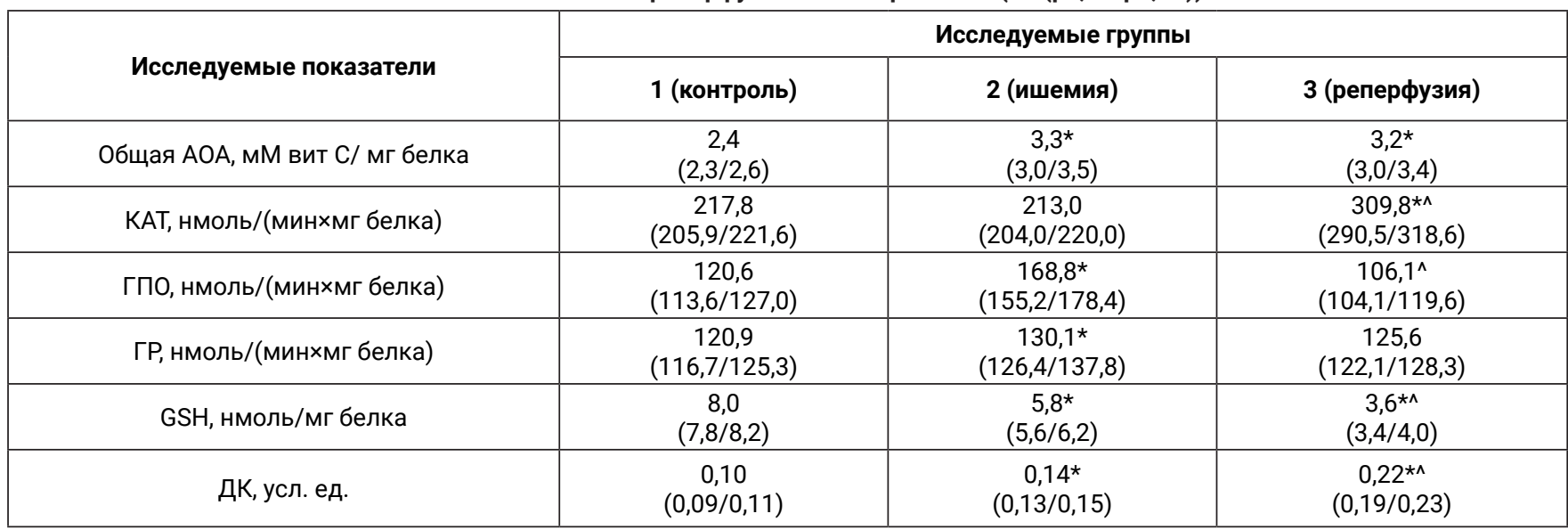

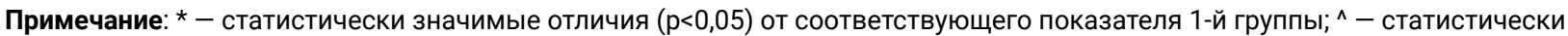
значимые отличия $(p<0,05)$ от показателя 2-й группы.

В цитозольной (постмитохондриальной) фракции были определены менее реактивные изменения ферментативной активности, но более значительные изменения неферментных компонентов и накопления диеновых конъюгатов (табл. 2). Так, в ишемическом периоде в цитозольной фракции определялись увеличенные на $40 \%$ значения активности глутатионпероксидазы, возвращавшиеся к исходному уровню в реперфузионном периоде. Похожим образом изменялась активность глутатионредуктазы. У животных 2-й группы в цитозольной фракции печени активность данного фермента была увеличена на 8\%, а у животных 3-й группы уже не отличалась от контрольных значений соответствующего показателя. Каталазная активность была значительно увеличена после 15-минутной реперфузии - на 42\% относительно контрольных цифр. Возможно, выявленные изменения обусловлены преимущественной локализацией каталазы в цитозоле и пероксисомах, а также более важной ролью этого фермента в защите цитозоля и его структур в сравнении с митохондриями. Общая антиоксидантная активность изменялась в цитозольной фракции аналогично изменениям в митохондриях, но более значительно. У животных 2-3-й групп анализируемый показатель был увеличен на 3738\% относительно значения соответствующего показателя контрольной группы. Также отмечалось значительное снижение уровня восстановленного глутатиона в цитозольной фракции печени крыс после ишемического периода - на 26\% и после реперфузионного периода - на 55\%. Содержание диеновых конъюгатов постепенно возрастало в печени исследуемых групп животных. В цитозольной фракции печени крыс 2-й группы уровень диеновых конъюгатов был увеличен на 40\%, а у крыс 3-й группы - уже в 2,2 раза. Полученные результаты, на наш взгляд, обусловлены адаптационным характером перестроек системы антиоксидантной защиты с увеличением активности ферментов и общей антиоксидантной активности. При этом ключевые адаптационные события в цитозоле происходят уже в ишемический период, а в митохондриальной суспензии в ходе реперфузии. Цитозоль в данных условиях, вероятно, играет роль буфера, принимая основное количество продуктов окислительных 
модификаций биомолекул, поставляя основное количество восстановленных эквивалентов глутатиона для функционирования антиоксидантной системы. Другим, также вполне вероятным, предположением является то, что в процессе выделения суспензии митохондрий поврежденные и разрушенные органеллы, а также их компоненты остаются в цитозольной фракции, таким образом, искусственно создается картина относительного благополучия состояния метаболических систем митохондрий, на фоне обширных патобиохимических нарушений в цитозольной фракции.

На наш взгляд, выбранная экспериментальная модель патологического процесса является достаточно мягкой, на фоне которой не следует ожидать разрушительных повреждений митохондрий, поэтому первое предположение кажется более вероятным. Вероятнее всего, общая картина патологического процесса более сложна и складывается из буферного влияния цитозоля и вымывания в цитозоль поврежденных компонентов митохондрий. Так или иначе, ясно, что для объективной оценки состояния антиоксидантной системы в ходе развития ишемических и реперфузионных повреждений следует определять показатели и митохондриальной суспензии и цитозольной фракции. При этом в митохондриальной суспензии следует обращать внимание на изменение активности ферментов метаболизма глутатиона, а в цитозольной фракции на изменение каталазной активности, содержания восстановленной формы глутатиона и продуктов окислительных модификаций биомолекул.

\section{Заключение}

Результаты исследований показали наличие особенностей патобиохимических изменений в суспензии митохондрий и цитозольной фракции после ишемии или реперфузии продолжительностью по 15 минут. В митохондриальной суспензии установлено адаптационное увеличение активности глутатионпероксидазы и глутатионредуктазы, особенно в период реперфузии. В цитозольной фракции наиболее значительно увеличение общей антиоксидантной активности уже в период ишемии и прогрессирующее снижение уровня восстановленной формы глутатиона на фоне роста количества продуктов окислительных модификаций биомолекул. Полученные результаты указывают на необходимость разработки не только митохондриально-ориентированной коррекции окислительных нарушений, но и на активную поддержку компонентам цитозоля, обеспечивающим основное накопление продуктов свободнорадикальных повреждений и последующее удаление их из клетки, что является исключительно необходимым для выживания.

\section{References}

1. Vaos G., Zavras N. Antioxidants in experimental ischemiareperfusion injury of the testis: Where are we heading towards? World J. Methodol. 2017;7(2):37—45. doi: 10.5662/wjm.v7.i2.37.

2. Sinning C., Westermann D., Clemmensen P. Oxidative stress in ischemia and reperfusion: current concepts, novel ideas and future perspectives. Biomark. Med. 2017;11(11):1031—40. doi: 10.2217/bmm-2017—0110.

3. Khodosovskii M.N. Correction of oxidative damage in the ischemiareperfusion syndrome of the liver. Zhurn GrGMU. 2016;4:20—5. (In Russ).

4. Cheng Y., Rong J. Therapeutic potential of heme oxygenase-1/carbon monoxide system against ischemiareperfusion injury. Curr. Pharm. Des. 2017;23(26):388498. doi: 10.2174/1381612823666170413122439.

5. Donadon M., Molinari A.F., Corazzi F., Rocchi L., Zito P., Cimino M., Costa G., Raimondi F., Torzilli G. Pharmacological modulation of ischemicreperfusion injury during Pringle maneuver in hepatic surgery. A prospective randomized pilot study. World Journal of Surgery. 2016;40(9):2202-12.

6. Basov A.A., Elkina A.A., Samkov A.A., Volchenko N.N., Baryshev M.G., Dzhimak S.S., Moiseev A.V., Fedulova L.V. Influence of deuterium-depleted water on the isotope $\mathrm{D} / \mathrm{H}$ composition of liver tissue and morphological development of rats at different periods of ontogenesis. Iranian Biomedical Journal. 2019;23(2):129-41.

7. Guan L.-Y., Fu P.-Y., Li P.-D., Liu H.-Y., Xin M.-G., $\mathrm{Li} \mathrm{W}$. Mechanisms of hepatic ischemia-reperfusion injury and protective effects of nitric oxide. World Journal of Gastrointestinal Surgery. 2014;6(7):122-8.

8. Li J., Li R.J., Lv G.Y., Liu H.Q. The mechanisms and strategies to protect from hepatic ischemia reperfusion injury. European Review for Medical and Pharmacological Sciences. 2015;19(11):2036-47.

9. Dzhimak S.S., Basov A.A., Volchenko N.N., Samkov A.A., 
Baryshev M.G., Fedulova L.V. Changes in the functional activity of mitochondria isolated from the liver of rat that passed the preadaptation to ultra-low deuterium concentration. Doklady Biochemistry and Biophysics. 2017;476(1):323—5.

10. Bradford M.M. A rapid and sensitive method for the quantitation of microgram quantities of protein utilizing the principle of protein-dye binding. Anal. Biochem. 1976;72:248-254.

11. Benzie I.F.F., Strain J.J. The ferric reducing ability of plasma (FRAP) as a measure of "antioxidant power": the FRAP assay. Anal. Biochem. 1996;239(1):70—6.

12. Karpishchenko A.I. Handbook. Medical Laboratory Technology. Sankt-Petersburg: Intermedika, 2002. (In Russ).

13. Bykov M.I., Basov A.A. Change of parameters in prooxidant-antioxidant bile system in patients with the obstruction of bile-excreting ducts. Medical news of North Caucasus. 2015;10(2):131-135.

\section{Библиографический список}

1. Vaos G., Zavras N. Antioxidants in experimental ischemiareperfusion injury of the testis: Where are we heading towards? World J. Methodol. 2017. V. 7 (2). P. 37-45. doi: 10.5662/wjm.v7.i2.37.

2. Sinning C., Westermann D., Clemmensen P. Oxidative stress in ischemia and reperfusion: current concepts, novel ideas and future perspectives. Biomark. Med. 2017. V. 11 (11). P. 11031-1040. doi: 10.2217/bmm-2017—0110.

3. Ходосовский М.Н. Коррекция окислительных повреждений при синдроме ишемии-реперфузии печени. Журн ГрГМУ. 2016. № 4. С. 20—25.

4. Cheng Y., Rong J. Therapeutic potential of heme oxygenase-1/carbon monoxide system against ischemiareperfusion injury. Curr. Pharm. Des. 2017. V. 23 (26). P. 3884-3898. doi: 10.2174/138161282366617041312 2439.

5. Donadon M., Molinari A.F., Corazzi F., Rocchi L., Zito P., Cimino M., Costa G., Raimondi F., Torzilli G.
Pharmacological modulation of ischemic-reperfusion injury during Pringle maneuver in hepatic surgery. A prospective randomized pilot study // World Journal of Surgery. 2016. V. 40. № 9. P. 2202-2212.

6. Basov A.A., Elkina A.A., Samkov A.A., Volchenko N.N., Baryshev M.G., Dzhimak S.S., Moiseev A.V., Fedulova L.V. Influence of deuterium-depleted water on the isotope $\mathrm{D} / \mathrm{H}$ composition of liver tissue and morphological development of rats at different periods of ontogenesis. Iranian Biomedical Journal. 2019. V. 23. № 2. P. 129-141.

7. Guan L.-Y., Fu P.-Y., Li P.-D., Liu H.-Y., Xin M.-G., Li W. Mechanisms of hepatic ischemia-reperfusion injury and protective effects of nitric oxide. World Journal of Gastrointestinal Surgery. 2014. V. 6. № 7. P. 122-128.

8. Li J., Li R.J., Lv G.Y., Liu H.Q. The mechanisms and strategies to protect from hepatic ischemia reperfusion injury. European Review for Medical and Pharmacological Sciences. 2015. V. 19. № 11. P. 2036-2047.

9. Dzhimak S.S., Basov A.A., Volchenko N.N., Samkov A.A., Baryshev M.G., Fedulova L.V. Changes in the functional activity of mitochondria isolated from the liver of rat that passed the preadaptation to ultra-low deuterium concentration. Doklady Biochemistry and Biophysics. 2017. V. 476. № 1. P. 323—325.

10. Bradford M.M. A rapid and sensitive method for the quantitation of microgram quantities of protein utilizing the principle of protein-dye binding. Anal. Biochem. 1976. V. 72. P. 248-254.

11. Benzie I.F.F., Strain J.J. The ferric reducing ability of plasma (FRAP) as a measure of "antioxidant power": the FRAP assay. Anal. Biochem. 1996. V. 239. № 1. P. 70—76.

12. Карпищенко А.И. Медицинские лабораторные технологии. Справочник. СПб: Интермедика, 2002. 600 с.

13. Bykov M.I., Basov A.A. Change of parameters in prooxidant-antioxidant bile system in patients with the obstruction of bile-excreting ducts. Medical news of North Caucasus. 2015. V. 10 (2):131-135. 
Corresponding Author: Popov Konstantin Andreevich, $\mathrm{PhD}$, Assistant of the department of fundamental and clinical biochemistry «FSBEI HE KubSMU of the Ministry of Public Health Care of Russia».

E-mail: naftalin444@mail.ru

ORCID: 0000—0002-3649-1361, SPIN: 9456-9710

Bykov Ilia Mikhaylovich ORCID0000-0001-7325-536

Tsymbalyuk Igor Yuryevich ORCID0000—0002-5711—6659

Denisova Yana Evgenievna ORCID0000-0003-1242—6909

Stolyarova Anzhela Nikolaevna ORCID0000-0002—5817-130X

Azimov Erustam AdamovichORCID0000—0002—3884-2436

Shurygina Larisa Alekseevna ORCID0000—0001—7978—217X

Ответственный за переписку: Попов Константин Андреевич, кандидат медицинских наук, ассистент кафедры фундаментальной и клинической биохимии ФГБОУ ВО «Кубанский государственный медицинский университет» Минздрава России.

E-mail: naftalin444@mail.ru

ORCID: 0000—0002—3649-1361, SPIN: 9456-9710

Быков Илья Михайлович ORCID0000-0001-7325—536, SPIN-код: 9977—6613

Цымбалюк Игорь Юрьевич ORCID0000-0002-5711—6659, SPIN-код: 4493-0738

Денисова Яна ЕвгеньевнаORCID0000-0003-1242-6909

Столярова Анжела НиколаевнаORCID0000-0002-5817-130X

Азимов Эрустам АдамовичORCID0000-0002-3884-2436

Шурыгина Лариса Алексеевна ORCID0000-0001-7978-217X 